Neves, D. \& Du Toit, A. (2013). Rural livelihoods in South Africa: complexity, vulnerability and differentiation. Journal of Agrarian Change, 13(1): 93-115

\title{
Rural livelihoods in South Africa: complexity, vulnerability and differentiation
}

\author{
David Neves and Andries Du Toit
}

\begin{abstract}
The livelihoods of South Africa's rural African poor have long been characterized by diverse activities, and intertwined with urban opportunities. This paper examines the interlinked nature of land, employment and rural livelihoods within contemporary South Africa, in order to examine aspects of how the rural poor survive. Drawing on a body of livelihood and poverty-oriented enquiry, several vignettes from South Africa's former 'homeland' communal areas are presented and discussed. Contemporary rural livelihoods are not only located in migratory networks and diverse livelihood activities, they are considered here as constituted in terms of four broad domains. First, they are forged within various land-based and agrarian activities. Second, they are often supported by small-scale, informal economic activities, both farm and non-farm. Third, they are frequently shaped by South Africa's comparatively well-developed system of state cash transfers and, fourth, they are patterned by culturally inscribed patterns of mutuality and social reciprocity. The complexity and vulnerability that typically characterize rural lives are examined in terms of these four domains, along with constellations of social differentiation with which they are intertwined.
\end{abstract}

\section{Introduction}

This paper draws on a body of livelihood and poverty enquiry to examine the livelihoods of South Africa's rural African poor. It seeks to help answer the question: how do South Africa's rural poor survive? Examining the interconnections among land, rural livelihoods and employment, the paper suggests that the answers to this question are, broadly, to be found in repertoires of productive activity (including agrarian activities) along with receipt of transfers, both public and private. These sources of livelihood-making are furthermore intertwined with widespread practices of mobility, which effectively connect rural dwellers to often distant locales and resources. The paper examines these sources of livelihood-making, the complexity and vulnerability that typically mark rural livelihoods, along with the constellations of social differentiation that these simultaneously reflect and reinforce.

The paper is structured as follows. The South Africa context, long subject to the dynamics of de-agrarianization, is briefly described, along with how rural livelihoods have been undercut by comparatively more recent dynamics, such as the decline of unskilled industrial employment. It is not only formal employment opportunities that have waned. South Africa's informal sector offers similarly limited prospects and succour for the poor. In light of these conditions, the paper considers how the African poor sustain their 
livelihoods in present-day South Africa, and the place of rural locales in these livelihoods. Grappling with this question requires careful attention to the rural context, including the dynamics of internal migration, demographic change and practices of householding, along with the wide repertoires of livelihood-enabling activities on which rural dwellers typically rely. These issues are examined and discussed in relation to case study data collected in South Africa's former 'homeland' communal areas.

The discussion then reflects on the empirical data, and seeks to explicate present-day rural livelihoods in terms of four domains. The first is how rural areas confer landbased endowments, but also provide crucial locales for social reproduction and sites for recuperation, retreat, retirement and risk mitigation in relation to urban locales and labour markets. Second, rural livelihoods frequently rely on small-scale, survivalist informal economic activities, both farm and off-farm. They invariably bridge local livelihood activities to distant locales, markets and value chains. Third, rural livelihoods in South Africa are increasingly shaped by a system of state cash transfers that intersect with rural markets, agrarian activities and livelihoods, in ways that are often poorly documented and dimly understood. Finally, rural livelihoods are shaped by culturally inscribed precepts and practices of mutuality and social reciprocity. These networks of exchange channel the earnings - from urban labour markets, informal-sector activity and state cash transfers - to others. The paper considers contemporary rural livelihoods in terms of these constitutive domains, and examines the complexity and vulnerability that typically mark them. It then examines the implications for rural social differentiation, examining how it is shaped by the above.

\section{Impoverished rural livelihoods in South Africa}

Rural livelihoods in South Africa today are marked by both continuities with the past and more contemporaneous changes. Long subject to the inexorable process of deagrarianization (Manona 1998; Bryceson 1996), South African rural livelihoods are also influenced by more recent developments such as the ascendancy of supermarket retail and expansion of state social assistance in the past two decades.The decline of smallholder African agriculture for most of the twentieth century was driven by racialized land dispossession and underdevelopment, in order to meet the labour demands of industrial capitalism (Wolpe 1972; Bundy 1979). Opportunities for smallholder agriculture became undercut by chronic African unemployment from the 1970s, amidst South Africa's increasingly capital-intensive growth path. The structural dynamics of urban-based, jobshedding, capital-intensive growth have only intensified since 1994 (Black and Khan 2002; Aliber 2003; Black 2010; Philip 2010), eroding remittances and migrants' reinvestment in rural areas. Processes of social and occupational change associated with de-agrarianization across Africa (Bryceson 1996; Bryceson and Jamal 1997) are highly pronounced in South Africa, in which agriculture contributes less than 4 per cent of GDP (Aliber et al. 2006, 54). In this way, the trajectories of de-agrarianization and deindustrialization are intertwined (Bank and Minkley 2005).

Present-day rural livelihoods in South Africa are marked by enduring racialized and spatial legacies of poverty. Using a poverty line of two US dollars per day, ${ }^{1}$ over 25

\footnotetext{
${ }^{1}$ In purchasing parity power terms.
} 
million South Africans were poor in 2000, with the proportion of the poor who are African remaining above 95 per cent regardless of the poverty line used (Leibbrandt et al. 2010). ${ }^{2}$ Poverty rates are successively lower amongst the coloured and Indian population groups, with whites constituting a tenth of the population but less than a single percentage point of the poor. Moreover, South Africa's high levels of aggregate income inequality have risen in the post-apartheid period. Income inequality within the four major racial groups has also increased, hence 'intra-African inequality and poverty trends increasingly dominate aggregate inequality and poverty in South Africa' (Leibbrandt et al. 2010, 4). Poverty in South Africa is not only widespread and persistent; it is disproportionately rural, with 72 per cent of the poor living in rural areas (May et al. 2000). Accordingly, the poorest provinces are those that encompass the largest of the former homeland areas: Eastern Cape, Limpopo and KwaZulu-Natal (Aliber 2003), with the former homelands accounting for 43 per cent of South Africa's population (Nobel and Wright 2012). Despite this, urban migration has reduced the relative proportion of the poor who live in the countryside. Leibbrandt et al. (2010), using a different poverty line to the above, suggest that the proportion of the rural poor has decreased from 62 per cent in 1996 to 56 per cent in 2001.

In light of the above realities and the trajectory of 'jobless de-agrarianization' (Bryceson and Jamal, 1997; Du Toit and Neves 2007b) described earlier, the informal sector of the economy offers little respite. Opportunities in South Africa's informal sector are paltry, and the sector is comparatively small despite enduring poverty and unemployment (Lund and Skinner 2003; Rogerson 2007). In this way, town and countryside, agriculture and industry, and formal and informal sectors offer constrained opportunities for accumulation for the poor in present-day South Africa. The problem of persistent rural poverty, however, is less one of the exclusion or estrangement of the economically marginalized from the economic mainstream, than their 'adverse incorporation' into the broader political economy of South Africa (Du Toit and Neves 2007b). South Africa's subalterns have long been incorporated into commodity relations: as consumers, social grant recipients, low-waged workers, informal-sector survivalists or the dependants of these groups. Finally, the prospects for social mobility remain inhibited by persistent inequality and enduring human development deficits, and the post-apartheid state's difficulties in addressing these (Seekings and Nattrass 2005; Hoogeveen and Özler 2006; Leibbrandt et al. 2010).

Impoverished rural livelihoods are constituted within practices of mobility and migration that have long linked rural African households to urban opportunities and resources in Southern Africa (Potts 2000). Rural households might helpfully be viewed as stretched between urban and rural (Spiegel et al. 1996). In this way, these multimodal households are often marked by fluid and often porous household membership (Ross 2003), and frequently eke out diversified and often hybrid livelihoods across geographical space.

\footnotetext{
${ }^{2}$ South Africa has no official poverty line at present. As the studies cited in this section use different poverty lines, direct comparison between the studies cannot be made.
} 
The key dynamics described above - limited opportunities for low-skill employment, constrained agrarian activities and truncated possibilities for accumulation - do not simply play themselves out in the economic realm; they are intertwined with social dynamics and cultural mores. The 1980 s collapse of racialized influx control and formal male labour migration coincided with a reconfiguring of long-standing practices of rural return, investment and accumulation. Despite its privations and exploitation, and the temptation to view subaltern life-worlds and subjectivities as easily 'captured in simple equations of domination and resistance' (Comaroff and Comaroff 1991), a century of male labour migration was intertwined with a cultural script of male provisioning and trajectories of matrimony and household formation. Diminished prospects for male migrant employment consequently not only alter the traditional material base of household formation and composition, but also feed into larger demographic and social transitions. Although these changes in the material and ideational basis of practices of contemporary householding are complex and analytically elusive, they are suggested by disparate phenomena: from changes in the conjugal contract, where well over half of South African children have no contact with their fathers (Posel and Devey 2006); a proliferation of concern, both official and academic, with 'masculinities' (Hunter 2005; Morrell and Swart 2005; Richter and Morrell 2006); and demographic evidence of household 'unbundling' - that is, increasing numbers of households, but smaller average household size (Pillay 2008).

In this context of limited and declining employment opportunities, how do impoverished rural residents survive? Any satisfactory answer involves a methodological practice of attention to local cases, praxis and subjectivities, to inform and understand better larger trajectories of social and historical change.

\section{Method}

This paper presents four vignettes derived from larger case studies conducted between 2005 and 2010. Although the processual and dynamic character of social life was captured by the case studies, the task of relating them to macro-social structures and developments could not rely simply on interpreting them as manifestations of larger processes. Instead, they were constructed as a form of extended case study, an approach derived from the Manchester school work of Gluckman and his classic example of situational analysis (Handelman 2005), and informed by the injunction to study 'upwards and outwards' (Handelman 2005) in order to link local social practice to larger structures and temporal trajectories.

The four case studies were developed during a succession of different research projects undertaken in two separate former homeland areas, in the Eastern Cape and Limpopo provinces respectively. 3 Three of the four case studies were collected in two villages in the former Transkei homeland of the current Eastern Cape province. These cases were part of a larger sample of forty-eight households, itself initially stratified from a much larger 2002 poverty survey.The data were collected during serial research visits, typically of a fortnightly duration, (intermittently over several months in the first year and then

\footnotetext{
${ }^{3}$ PLAAS conducted research in the Eastern and Western Cape on aspects of vulnerability, labour markets and social protection (Du Toit and Neves 2006), aspects of self-employment (Du Toit and Neves 2007a; Neves et al. 2011) and state cash transfers (Neves et al. 2009), and in Limpopo province on livelihoods and land reform (Aliber et al. forthcoming).
} 
approximately annually thereafter) using in-depth household interviewing, detailed life histories and observational methods.

The combination of detailed life histories and several years of return visits imparted a strong longitudinal quality to the case studies and the vignettes abridged from them presented below. Secondary interviews and analysis were conducted with others outside of the focal households4 in order to better understand practice through time and space.

The single Limpopo-based case study vignette was initially included in an entirely different research project, which examined aspects of rural livelihoods following land reform interventions (Aliber et al. forthcoming). It was therefore not included through the initial survey and selection process, unlike the Eastern Cape case study vignettes. However, the class profile and employment trajectory of its chief subject (Ramena) suggest some useful comparison with the other vignettes, even if this household is amongst the least poor of the four. The key agrarian and market dynamics, which this vignette serves to illustrate, justify its inclusion and value to the current analysis.

Each of the vignettes is specific and particular. This analysis makes no claims to their generalizablity to all impoverished rural South African households, nor suggests that these are invariant 'models' of households or processes. Instead, the vignettes offer critical vantage points from which to consider constitutive domains of rural livelihoods, in a specific type of context, namely South Africa's former homeland communal areas.

\section{Case study vignettes}

\section{Ramena}

An energetic 60-year-old man, Ramena lives in a Limpopo village in a communal area, where he occupies a cluster of buildings adjacent to a busy feeder road outside a town. Enclosed by a high wall, his compound includes an informal abattoir, retail butchery and 'eating place' (a communal room that serves a limited selection of meals and alcohol). Apart from rearing cattle (ninety head grazed on both communal and leased, privately owned land), Ramena's household engages in a number of other activities including goat production (approximately twenty head), and the supply and transport of building sand using Ramena's two tipper trucks. Gathered from the banks of a local river, the sand is also used to make concrete building blocks for resale. Ramena's wife and daughter are paid for assisting in running the abattoir and butchery. Ramena also has an adult daughter doing vocational training in Pretoria, whom he continues to support financially, in anticipation of her potential formal-sector employment prospects.

Having grown up in the district, Ramena and his family were forcibly removed from an adjacent farm when he was a child. As an adult, he worked in the industrial heartland of Gauteng as a bus driver for two decades, before returning to the district with a retrenchment package in the 1990s. With work experience and his accrued capital, he started a haulage business and acquired his current business site. Ramena used the proceeds from this business to buy a concrete block making machine, which he used to

\footnotetext{
${ }^{4}$ Enquiries were conducted amongst both kin and households linked horizontally to the focal households, and with more community-level informants.
} 
build the compound. He constructed the abattoir and butchery, and bought butchery and refrigeration equipment in an auction. Despite a lack of formal training, Ramena considers that it is not particularly difficult to butcher cattle.

Ramena's butchery, opening for a decade, resells ten boxes of pre-packaged chicken a month, but focuses primarily on beef. His cattle production, abattoir, butchery and 'eating house' are vertically integrated: livestock are reared, slaughtered, and retailed as raw or cooked meat. Yet his activities are even more complex than this: while some cattle slaughtered at his abattoir (which supplies only Ramena) are his, others are purchased either from African smallholders in the communal area, or from white commercial farmers via formal auctions. Conversely, Ramena sells many of his betterquality cattle at auction, rather than processing them himself. He explained the practice of selling his own cattle and buying in others by describing the local market as highly price sensitive and requiring a 'lower quality' meat: 'You see the people from here are not able to see the difference ... they think meat is meat.' Having invested in a superior bull and heifer to improve his herd, Ramena knows that his better-quality animals would not fetch a good enough price locally.

Ramena slaughters approximately one head of cattle a week (potentially costing R5,000-6,000 if bought at auction), but only between ten and fifteen of the cattle that he slaughters annually are his own. In 2009, he sold sixteen of his animals at auction. He complained that his profitability was undermined by the high monthly costs that he incurs - electricity for refrigeration, transport for the livestock, cleaning consumables and packing materials for the meat - and a license fee, although the latter is paltry and his abattoir is unregistered. He estimated conservatively an income of R1,500 from each head of cattle slaughtered, from which his other enterprise costs need to be met. A rough estimate gives him a gross annual margin of R41,000 on the butchery, excluding his regular payment to his wife and daughter, and R56,000 from livestock sales at auction. He was not particularly rich, but this income from his livestock enterprise/meat enterprise alone doubtlessly represented several multiples of the average household income in the area.

\section{Nosomsi}

A 2002 survey revealed Nosomsi's household, in the deep rural region of the former Transkei homeland of the Eastern Cape, as amongst the poorest of the respondents. 5 Situated 2 hours' drive on unpaved roads to the nearest town, the household reported 'no paid work', and no income other than a state old age grant (SOAG) and diminutive wage earnings. Yet despite being income poor, the household had been able to invest in several head of livestock, and a chest freezer powered by bottled gas, a rare asset in the village.

A 2005 visit to matriarch Nosomsi at her large and well-furnished compound revealed an obese, and moderately immobile, elderly woman with a complex livelihood strategy. She relied on her adult children, who worked in various urban centres - particularly her son Fikile, who was a bakery manager in a nearby town and remitted at least R400 monthly. As Nosomsi struggled to support her numerous co-resident grandchildren, Fikile bought the freezer to enable his mother to augment her income through retail. She sourced pre-packaged meat for resale from an

\footnotetext{
${ }^{5}$ She was included in an earlier (2002) PLAAS survey of the area, and placed in the lowest (poorest) income quintile.
} 
adjacent town, and beer from a local bottle store, for the small tavern she ran from the house. Her two teenage grandsons were an integral part of the business. They collected the beer for their grandmother, and helped serve patrons in the small tavern, from which Nosomsi estimated that she made R600 per month in 2005. The SOAG supported Nosomsi's business by enabling her to buy stock and offer customers credit, and helped pay for agricultural inputs such as ploughing for her small farm, worked by her grandsons and hired agricultural labour. In 2005, these economic activities saw the household more than doubling Nosomsi's pension income. Finally, she routinely stored perishables for other villagers in her freezer, a considerable favour in a village without electricity.

The good rains of 2008-9 saw a harvest of eleven bags of maize from a large homestead garden, and the hiring of several weeks of agricultural labour. Nosomsi's adult children, including Fikile and his family, returned annually to help with the harvest. While the cost of the inputs seemed close to the value of the harvest, in response to detailed questioning, Nosomsi impatiently explained that cultivating maize is a long-standing tradition. It also kept both her grandsons out of mischief and enabled her to offer employment to other villagers.

The narrative of the key benefactor, son Fikile, is also revealing. He explained how he and his siblings were raised by their grandparents in the village while their mother, Nosomsi, was a domestic worker in distant Durban. Fikile joined his mother in Durban, and worked as a cleaner in a supermarket in the early 1990s, slowly working his way up the ranks into the bakery. When his aging mother retired to the village, he bought her the freezer. Once Nosomsi secured a SOAG, the immediate pressure on Fikile eased. He scaled back on his working hours at the supermarket in order to complete his education. Once qualified, his position in the supermarket improved. In 2005, he was a bakery manager; by 2008, he was employed as a mid-level executive in a large listed confectionary supply company.

Fikile supported not only his mother, but also his other siblings, nephews and nieces. These included a brother after he was retrenched, along with the tertiary education of several younger sisters. Throughout the research period, Fikile maintained his support for his mother, regularly visiting with gifts and stock to resell. Pointing to a new rainwater tank purchased by her daughter in 2009, Nosomsi was clearly proud of adult children. She explained that they all worked, 'none of them are scarce' (absent or inattentive) and they supported her. Her old age grant was now spent on funeral insurance, toiletries, smaller grocery items throughout the month: 'Bandincedise ngezinto ezincinci' ('it helps with the smaller things'), she explained.

\section{Kwanele}

Kwanele was a tall and imposing beaded rural patriarch, who toiled for decades in the industrial heartland of Gauteng. Despite little formal education, he had risen through the ranks, to eventually secure reasonably skilled employment as a machine operator, which enabled him both to invest in his substantial rural homestead and school his four eldest sons at various major urban centres. In 2005, 55-year-old Kwanele had been recently retrenched and returned to his homestead in the former Transkei. He supported a total of thirteen dependants: his wife, two adult brothers (one mentally ill, the other reportedly a dissolute drunkard), five children (and a granddaughter born to one of his unmarried daughters), along with the four sons living at distant urban centres. 
Two of the non-resident sons were completing secondary schooling, one in the regional centre of Mthatha, and the other in the distant Gauteng township of Sebokeng, where Kwanele lived when employed. A third son, also in Sebokeng, who had recently completed an advanced certificate in 'mechanics' from a tertiary institution university, had obtained his heavy vehicle drivers' licence and was seeking employment. The fourth son was studying at a reputable tertiary institution in Pretoria, and repeating a failed course for his 4-year commerce diploma.

After his return in 2005, Kwanele enthusiastically busied himself with agricultural production, pressing his children into help after school. Apart from selling vegetables, he planned to travel to commercial farmers in the area adjacent to the homeland in order to secure bloodstock in order to improve his small herd of seven cattle. His entrepreneurial efforts to sell his surplus vegetables were frustrated by the ethos of communalism and villagers' requests that he simply give them vegetables. In response to questions about his adult brothers, he was critical of them, but explained he had resigned himself reluctantly to supporting them, as they were family.

At this point, in 2005, the household was largely living off the fixed income of his retrenchment package. Kwanele made monthly remittances of R1,650 to his four sons, the minimum needed for their subsistence. This excluded college fees and other specific expenses: Kwanele was incredulous at how a single book had cost R500:'net een boek!' ('only one book!') he emphasized in the Afrikaans learnt during his urban employ. That their sons were being educated at various metropolitan tertiary institutions was a source of pride to Kwanele and his wife. They justified the expense by their sons' improved employment prospects, and in anticipation of them supporting the household and its many dependants.

By 2008, Kwanele continued his plot and livestock husbandry, but was opportunistically running a small Spaza shop from his homestead after a larger local store closed. However, the earlier certainty of their sons' employment prospects had made way for doubt. Kwanele's wife wept at recounting the succession of low-prospect, low-wage casual jobs the sons worked, along with the failure of one son to complete his expensive course.

By late 2009, however, their fortunes had turned. One son was accepted into an artisan training programme of a multinational petrochemical company, and quickly recruited his brother. Although they were not yet remitting, both Kwanele and his wife were relieved at the prospect of their sons' securing solid skilled employment. At this point, his Spaza shop had wound down, as the local store reopened. In addition, a large concrete block hall emerged in the corner of Kwanele's kitchen garden. Long active in the local church, Kwanele was now building his own church and recruiting a congregation. Its construction was funded by paltry donations and his diminishing retrenchment savings. Kwanele confided that his R100,000 retrenchment package (worth approximately the annual value of the SOAG for a period of 10 years) was almost exhausted, but explained that he would soon qualify for a SOAG himself. 


\section{Chuma}

Chuma was a woman in her thirties, who lived with her three young children in what was, even by village standards, extremely modest accommodation, consisting of two small and barely furnished mud block huts, one for cooking and the other for sleeping. She lived in a village in the former Transkei, where the rolling grassy hills of the district made way for an inhospitable and rock-strewn area. Alongside the two huts occupied by Chuma and her children were the ruins of a third collapsed structure and an abandoned kraal (cattle byre). Chuma was amongst the poorest and most marginalized of all households encountered in several years of intermittent field research in the rural Eastern Cape. Between 2005 and 2006, her sole source of regular income was a single child support grant, which she augmented with low-paid and laborious menial labour within the village. Although all three of her children were hypothetically entitled to a child support grant, two of them lacked the necessary documentation (birth certificates). In a context in which the child support grant has high levels of uptake, the failure to access it suggests extreme marginality and individual incapacity. Chuma's household engaged in no agricultural production, and she enumerated a single dog when questioned on livestock. Furthermore, interviewing her was generally difficult. Unlike most respondents who readily warmed to the task of relating their personal narratives, Chuma remained a reticent interviewee during several visits over the course of several years. While she might occasionally utter a mischievous aside, she remained guarded, laconic and distant.

The air of resigned passivity seemed to hang over Chuma and was evident in relation to other aspects of her life. When a tractor struck and damaged her hut, she obstinately waited for the errant tractor driver to repair the damage that she could repair herself. Livestock gradually entered the hut and consumed her modest maize store (two bags for the use of her stake in the communal planting fields of a local development project). Similarly, she eschewed the customary flurry of repainting and tidying of homesteads, in preparation for Christmas time family reunions. In the context of annual mass migratory returns and the high value placed on kinship, this indifference was noteworthy and incongruous. However, Chuma's passivity and even resistance became far more comprehensible when viewed in the light of the micro-politics of her place within her kinship networks. Her inaction was far more studied and deliberate than it might first have appeared.

Even by local standards, the composition of the household at Chuma's compound had changed radically in the recent past. When the household was first surveyed in 2002, its members consisted of Chuma's 3-year-old daughter, 15-year-old nephew and 69year-old grandmother. Chuma was living at a distant urban centre with her then partner. Soon afterwards, in late 2002, her grandmother died and the nephew was promptly relocated to Cape Town. This and the death of Chuma's stepmother in 2004, catalysed Chuma's return to the village sans partner, along with two of her older children, reportedly as the product of a fiat by her three half-brothers during a fateful family gathering in the Western Cape. Having returned reluctantly, Chuma readily admitted to finding village life arduous and monotonous. However, with three young children to care for, slim prospects for marriage or urban employment, and weak urban entitlements, she had little choice. She was despatched to tend to their rural homestead, while her brothers were to remit money. 
Over the course of several interviews with Chuma and several other villagers, two facts became apparent. The first was that 'her brothers' were not her brothers or stepbrothers; instead, they were more accurately her cousins. The second was that Chuma's distant kin reneged on their agreement and sent very few and erratic remittances; hence her current predicament.

The consequence was that Chuma was effectively marooned in the rural Eastern Cape. Although she performs essential work for her kin, by continuing to occupy the house (in a context where property rights are often bound up with communal recognition, occupation and use), she is marginal and relatively powerless within her family network and unable to successfully press a claim for reciprocation. She was constrained to survive on a single child support grant, and on inconstant and poorly paid menial work for others (mud brick making and domestic work) in the hardscrabble patronage of a handful of village-based benefactors.

\section{Understanding rural livelihoods}

Drawing on the vignettes presented, this section seeks to consider how marginalized rural livelihoods are constituted in terms of the four domains identified earlier. First, we discuss how the rural base affords opportunities for engagement with a variety of livelihood-supporting activities, along with how it provides both a site for engagement with urban opportunities and a zone of retreat from urban pressures. Rural locales are then examined as zones for complex repertoires of productive economic activity, which include - but are not limited to - agriculture. Then, we move on to South Africa's system of state cash transfers and, finally, to practices of social reciprocity, as pieces in the puzzle of conceptualizing present-day rural livelihoods.

\section{Impoverished livelihoods and the uses of the rural}

How the rural poor engage with the locales within which they live, and the meanings that they accord to rurality, are diverse and heterogeneous. Subaltern rural livelihoods in South Africa have long been linked through oscillatory migration to distant urban locales and intertwined with urban fortunes. These linkages have persisted in the postapartheid era (Hart 1996, 2002; James 2000, 2001). Urban sites not only provide potential employment opportunities; they also offer the promise of superior access to amenities and infrastructural services (electricity, piped water, transport links), and higher-quality social services such as schooling or public health care. Conversely, the countryside retains residents and attracts urban returnees, because it is an important zone for retreat from urban labour markets, as in the case of Kwanele. Connected to urban areas through entrenched practices of oscillatory migration, rural locales remain common sites for rural retirement, and confer a safety net for livelihood shocks such as death, illness and job loss. The persistence of oscillatory migration in the postapartheid period, and the relative absence of 'urban transition' with the dismantling of apartheid-era influx control, is attributable to the enduring precariousness of urban labour markets and livelihoods (Mabin 1990).

Impoverished migrants readily enumerate the virtues of rural living in terms of its lower-cost living, through its (relatively) non-commodified land, housing, water and even fuel resources. Rural sites 
also provide the 'back-end' of spatially extended care chains (Hochschild 2000), and function as important bases for social reproduction. For instance, a relatively common response to an urban livelihood shock is to reconfigure urban commitments by despatching non-economically active household members such as children back to the rural areas (Du Toit and Neves 2006). The small selection of vignettes presented contain both examples of rural return retirement (Kwanele, Nomsomi and Ramena) and three-generation or skipped-generation (grandparent/s and grandchildren) households such as those of Nomsomi and Kwanele.

South Africa's rural residents have long been absorbed into commodity relations and spatially extended systems of production and consumption. Town and countryside are therefore not only linked by enduring patterns of oscillatory migration, but also resource flows. The evidence suggests a decline in remittances over time (Seekings et al. 1990). These are attributable to a complex combination of declining employment opportunities, the need to retain resources for household 'unbundling' and weakening entitlements associated with changing social mores (Seekings and Harper 2010). Yet remittances are still evident, and continue to be significant vectors of material provisioning for a stratum of rural households. The case studies reflect elements of this, and the complexity of remitting behaviour. For Nosomsi, the ebb in remittances of her son Fikile enabled him to invest in his education, improve his employment and subsequently increase his flow of resources to her. Similarly, Kwanele provides a counterpoint to the conventional narrative of one-way urban remittances from town to countryside. Instead, he sends money to his urban-based sons.

Apart from migration and remittances, South African's rural poor also engage in in-situ productive activity. Despite the inexorable process of de-agrarianization, and wide variations in the availability of agro-ecological, social, institutional and market conditions that enable small-holder agriculture, land remains a significant resource for the rural poor (McAllister 2001). Ranging from smallholder agricultural production (Aliber et al. 2006; Aliber and Hart 2009) to the intensive cultivation of homestead plots (Andrew and Fox 2004), and practices of natural resource harvesting (Shackelton et al. 2001), land remains an important component in the livelihood repertoires of the rural subaltern (Van Averbeke and Khosa 2007). As the prospects for agrarian self-sufficiency receded almost a century ago in South Africa, agricultural production is a precarious and comparatively small-scale activity. Yet it is crucial to the people, estimated at between 1.25 and 3 million, who engage in it (Aliber and Hart 2009). While the vignettes demonstrate varying levels of agricultural production, it remains a key livelihood activity for many rural households, and provides a valuable analytical lens through which to view the wide array of their objectives and livelihood projects. Even the small selection of vignettes presented reveal quite different engagements with farming. Much informal economic activity encodes within it subtly different objectives: it can range from supporting food security or generating income to mitigating risk or even managing social claims from others (Petersen and Charman 2008; von Broembsen 2008; Neves and Du Toit 2012). While the potential objectives or envisaged outcomes of farming are typically conceived as varying between the points of own consumption and the market, they can in fact be far more nuanced and differentiated that this dichotomy suggests.

Nosomsi's maize growing was a fairly marginal activity in agricultural terms, but crucial in at least three other respects. First, it kept her teenage grandsons dutifully engaged and enabled her to assert her generational authority over them, in a rapidly changing social context in which gender 
and generational dynamics are shifting and often contested (see Delius 1996; Bank 2002). Second, Nosomsi's adult urban-based son, Fikile, routinely participated in harvesting the crop with his wife and children. This was a potent affirmation of his stake in the rural homestead, and the welfare of his mother. Each season's return re-enactment of this allegiance was significant in a context in which long-term urban residence, and middleclass lifestyles, can potentially erode commitments to rural identities and kin. Third, Nosomsi's maize production saw her hire agricultural labour, typically in response to neighbours' requests for material assistance. Her offer of (relatively poorly paid) ad hoc employment was therefore an effective way of deflecting and channelling redistributive requests within the village context. It enabled her to draw claimants into relationships of mutuality and petty patronage, thereby cementing her continued position as a minor benefactor within the village. This is a noteworthy consideration in a patriarchal context in which an elderly, mobility-impaired, female (de facto) household head might otherwise be more easily marginalized. This case is therefore an example of farming directed by a range of instrumental ends, which include but are irreducible to the consumption or financial value of the crop itself.

In short, rural livelihood activities are sustained in rural contexts, patterned by histories of migrancy and widespread cultural imaginaries of these rural locales as authentic home (James 2001; Ngwane 2003). Kwanele's enthusiasm for his bucolic rural home, and Nosomsi's assertion of the long-standing tradition of maize cultivation, stand in contrast to Chuma's alienation and thinly veiled unhappiness with her rural lot.Therefore, understanding rural livelihoods demands not only attention to the rural as livelihood ballast in relation to urban opportunities and resources, but also as a space in which individual aspirations and collective household livelihood projects are played out (Seekings 2008). In the vignettes, the rural is an important site of these complex projects and aspirations for all but Chuma. Finally, these dynamics are often marked by the intimate politics of gender and generation, and hence cultural as well as material contestation, of the sort evident in Chuma's estrangement from her male kin's desires (and authority). Bank (2002) notes some of the gendered fissures in these livelihood-making projects and documents some inverse dynamics. He describes the proficiency with which rural women transact within networks of gendered social solidarity and the relative adeptness with which they respond to successive rural development interventions. This is contrasted with their male counterparts, who are both alienated from the improvisational 'woman's work' of small village income-generating projects and trapped in the fading fantasy of formal employment as industrial labour.

\section{Rural livelihoods and economic informality}

Rural sites are locales in which complex repertoires of economic activity, in addition to farming, take place. Rural livelihoods therefore need to be conceptualized as constituted though both farm and non-farm activities, formal and informal, and waged and ownaccount economic activities. It is informal self-employment or petty commodity production that is the specific focus here. Early definitions of economic informality described marginal and low-productivity activities outside the regulatory ambit of the state and tax system (Hart 1973). More recent definitions of economic informality are employed-based, defining it in terms of the precarious and unprotected nature of employment, yet both conceptions remain equally useful here. In South Africa, 
economic informality is undertaken in the interstices of a powerful industrial economy, predominantly by African women who glean relatively low average incomes (Devey et al. 2005; Rogerson 2007).

Despite high levels of poverty and unemployment, the informal sector is, by developing economy standards, comparatively small, at no more than a fifth of the workforce (Cichello et al. 2005).The reasons for this are numerous, but key factors include the legacy of colonialism and apartheid, which inhibited African entrepreneurship, various credit, information and skills deficits, and high infrastructure costs (Lund and Skinner 2003). Furthermore, these conditions exist in a context that combines developing-country conditions with a powerful, and monopolistic, formal economy, which serves to effectively 'crowd out' economic opportunities for small or informal enterprises (Philip 2010; Neves et al. 2011). In this way, the factors that inhibit informal economic activity, and deepen the vulnerability of the economically marginalized, are similar to those that systematically undercut the prospects for smallholder agriculture. Yet despite the considerable constraints that they face, many rural households do engage in various forms of informal economic activity.

The case study material illustrates these dynamics and the 'survivalist improvization' (Davis 2006) of which much informal economic activity is part. Informal economic activity may be both directed to multiple potential objectives (as illustrated by the case of Nosomsi's maize cultivation in the previous section), and frequently marked by a highly responsive and dynamic quality. This contingent, improvisational quality is illustrated in the case of Kwanele who, after his rural return, engaged in livestock farming for the local market. He scaled this back to concentrate on his small Spaza shop during the closure of a larger local store, but withdrew when his competitor reopened, refocusing his energies and material resources on building a church and congregation. Even Kwanele's ecclesiastical ambitions, while doubtlessly underpinned by a strong set of valuational commitments, cannot be viewed apart from the imperatives of securing a livelihood, through their ability to bolster his status in the village and, potentially, local networks of patronage and mutuality.

Informal economic activity in South Africa is typically tightly intertwined with the formal sector, in terms of linkages of capital, inputs, production and employment - churning employment between the formal and informal sectors is commonplace (Devey et al. 2006). Histories of formal-sector employment can confer the capital, skills and productive assets that are often perquisites for informal economic activity. In the case studies, respondents frequently drew on these resources, accrued during previous episodes of formal-sector employment, to start or run their informal enterprises. This is especially so concerning men, who are more likely to have had been employed in the formal sector (Neves and Du Toit 2012). Both Ramena and Kwanele retreated from urban labour markets with capital (a retrenchment package), material assets (cattle, vehicles) and skills, from Ramena's driving to the less tangible but equally important social confidence and linguistic proficiency in English and Afrikaans that Kwanele draws on to negotiate with commercial farmers to improve his herd. 
The capacity to engage in informal economic activity is not shared equally by all impoverished households but, rather, is an extension of a household's ability to leverage existing assets and surplus labour capacity. For instance, higher informal-sector earnings have been found to correlate statistically with both formal-sector employment and a marital relationship (Neves et al. 2011). Successful informal economic activity frequently demands that household labour constraints be overcome. The diverse cast of labour required to engage with economic activity is exemplified by mobility-impaired Nosomsi's agricultural production, which draws a shifting cast of hired labour, the toil of her grandsons and the seasonal arrival of non-resident kin who help with harvesting. Kwanele's children are similarly drawn into his agricultural activities, while Ramena's wife and daughter are modestly remunerated for helping him in the beef enterprise. The crucial role of the ability to mobilize intra-household labour is evident in Nosomsi's unpaid minor grandsons, who regularly collect the liquor from a local store and dutifully serve her tavern patrons. In resource-poor rural contexts, young pre-teenage children are routinely drawn into the demands of social reproduction. Even in households that do not farm, the requirements of water and fuel collection, and demands of care work in households with many dependants, can be considerable burdens that require the careful management of household labour (Du Toit and Neves 2006; Hunter 2006).

Successful informal enterprise operators frequently seek to exploit small niches and fine gradations of value between the formal and informal sectors (Neves et al. 2011). In the resource-poor former homelands, local markets are often comparatively 'thin' and geographically isolated. Much of the disadvantage that marks the informal sector is evident in the asymmetry of its linkages to the formal economy (Neves et al. 2011). It is backward linkages from the formal sector that predominate, because virtually all commodities sold in the informal sector originate in the formal sector ${ }^{6}$ (Philip 2010). Conversely, there are relatively few forward linkages from the informal into the formal sector. Hence beef producer Ramena was not only unusual and noteworthy for creating a vertically integrated beef enterprise, but also for his adeptness at building forward linkages into the formal economy (via commercial cattle auctions). Ramena's sophisticated enterprise sought to effect an arbitrage between the commercial cattle market and the demands of his price-sensitive local village consumers, in order to appropriate slivers of value (Neves and Du Toit 2012).

Successful informal economic activity often relies on the ability of those in the sector to manage and evade forms of formal, state-based economic governance. Wider regimes of governance, particularly in the liminal zones of South Africa's communal areas, consist of competing and overlapping layers of authority. One of the most influential is the institution of the hereditary chieftaincy, which continues to exercise authority over large swathes of the communal areas (Hendricks 1990; Ntsebeza 2006). Residents of these areas are thus both citizens of formal, civic authority but also the subjects of traditional authorities (Mamdani 1996). Chiefs exercise their authority in locales where the modern South African state and its appurtenances are either relatively thin on the ground or altogether absent. These patterns of rural governance create spaces in which

\footnotetext{
${ }^{6}$ Traditional medicinal herbs are one significant exception to this.
} 
productive economic activities, such as Ramena's butchery, Nosomsi's liquor retail and even Kwanele's church building, are relatively untrammelled by regulations concerned with the environment, health, liquor retail or even land-use planning. These petty entrepreneurs are less rigorously policed, or subject to modern forms of governmentality in the ethnic enclaves of South Africa's enduringly 'black' and rural homeland spaces than they would be elsewhere. Indeed, throughout Africa, much economic activity is subject to forms of economic governance outside the purview of the formal state (Guyer 2004; Roitman 2005).

Finally, the vignettes point to how economic activity is shaped by social imperatives and embedded in social networks (Meagher 2010). Informal traders often seek to exploit small networks, yet this forging and strategic deployment of 'social capital' exacts costs in the forms of various entitlements and redistributive claims (from kin, customers, in the form of criminal victimization etc.). Much of the challenge, and work, of economic informality is the demand of managing these claims (see Ferguson, this issue). Examining the ascendancy of a class of African small retailers in Qwaqwa, Bank (1997) noted how they mobilized their accrued social and cultural capital in order to trade their cattle for stock. However, they were careful to do so in ways that did not disavow the social and cultural values cattle typically embody (see Ferguson 1992). In so doing, each aspirant trader was less a profit-maximizing homo economicus than a social actor who forged hybrid understanding of the meaning of property and the social relations within which their enterprises needed to be embedded in order to succeed' (Bank 1997, 201). Economic informality is therefore often simultaneously enabled and constrained by social relations.

\section{State social cash transfers}

A third component is South Africa's system of means-tested state cash transfers. Comparatively extensive for a developing country, non-contributory social assistance grants are received monthly by 15.7 million individuals, over a quarter of the population (Sassa 2012). Children, the disabled and the elderly are the super-ordinate categories of beneficiaries; there is no social assistance for non-disabled, working-age adults. Contributory unemployment insurance does not reach the majority of unemployed working-age adults, as most have never been employed. Early twentieth-century social pensions for whites were patterned on the classic European welfare model, and began to extend to 'natives' by mid-century, albeit reflecting the racially allocative principles of apartheid. The value of African old age pensions rose in value to equivalence with whites with the advent of democracy (van der Berg 1997). The SOAG represents almost twice the median per capita income for Africans (Case and Deaton 1998), and has a current value of R1,200 per month. The child support grant has been the fastest growing and largest category of transfers in the post-apartheid period (Pauw and Mncube 2007). Although approximately a quarter of the value of the SOAG, it is received by over 11 million beneficiary children as an (effectively) unconditional cash benefit, payable to a 'caregiver' rather than a narrowly defined biological or 'foster' parent (Case et al. 2005).

The combination of a progressive ${ }^{7}$ tax system, and (relatively) generous transfers serves to temper South African's globally leading levels of income inequality (Seekings 2002). Although

\footnotetext{
${ }^{7}$ In economically redistributive terms.
} 
Samson et al. (2004) claim that state cash transfers reduce the Gini coefficient by 7 per cent, the inequality-reducing effects of social transfers pale alongside their success in reducing poverty amongst the very poorest households. So impoverished are South Africa's poorest that receipt of a social grant effectively lifts many recipient's households out of the lowest income decile. Robust welfare effects are also associated with cash transfers, including improving nutritional status, reducing morbidity and stunting (Devereux 2001), and elevating educational enrolment and outcomes (Case et al. 2005; Budlender and Woolard 2006). Furthermore, social transfer income is routinely shared with household members who are not its designated beneficiaries, particularly when women are recipients of the transfer (Duflo 2003; Lund 2006). Apart from ameliorating poverty, state cash transfers have a range of other consequences, including various household demographic, labour market and economic effects. ${ }^{8}$

In terms of household demography, as state cash transfers often represent the largest regular infusion of cash into rural areas, many households are effectively formed around a recipient pensioner (Woolard and Klassen 2004). The SOAG is effectively the material lynchpin for many rural households, particularly the three-generation or skipped-generation (grandparent/s and grandchildren) households that are ubiquitous in rural South Africa. This effect is magnified by the fact that the social pension is particularly well targeted to the rural areas and women. Women are the vast majority of its recipients because they have higher life expectancy, receive it earlier, ${ }^{9}$ and are less likely than men to receive a private pension (Ardington and Lund 1995).

The evidence of SOAG effects on labour market engagement is contested. Some early research suggested that an old age pension is negatively correlated with labour market involvement by working-age adults within recipients' households (Bertrand et al. 2003). Conversely, others suggest that pension income facilitates labour market engagement (Kingdon and Knight 2000; Keswell 2004). Detailed research that examined distant non-resident household members inverted the original negative correlation and found that SOAG receipt has a positive effect on labour market supply (Posel et al. 2004). Receipt of a SOAG is associated with decreased numbers of prime working-age women and increased proportions of young children within households. It has been suggested the SOAG generates these effects by both providing the material resources required for rural outmigration and enabling older women to look after grandchildren (Posel et al. 2004).

The absence of credible counterfactuals and the fact that supporting economic growth is seldom an explicit or measured objective make it difficult to gauge the economic effects of state transfers and their impact on productive economic activity (Barrientos 2008). Yet some evidence from Latin America suggests that state transfers support investments in productive physical capital and smallholder agriculture, generating multipliers in excess of 150 per cent of the value of the grant (Sadoulet et al. 2001). For as Devereux notes: 'At the individual level, even tiny consumption-smoothing public transfers can have "mean shifting" outcomes, since the capital-constrained poor often invest some incremental income in farming or small-scale enterprises' $(2001,515)$. Much of the value of state transfers also resides in the predictability and regularity of their receipt, particularly for beneficiaries whose lives are filled with contingency and

\footnotetext{
${ }^{8}$ These effects are most robustly documented for the long-standing, and larger-value, SOAG.

${ }^{9}$ The male age of eligibility has recently been reduced to 60 years of age, for parity with women.
} 
uncertainty. Cash transfers therefore potentially enable recipients to overcome liquidity constraints, transcend the need to engage in precautionary low-risk activities (or crops) and keep savings in liquid but low-yield forms.

In South Africa, there is evidence that cash transfers support investments in productive assets and a wide range of activities (Ardington and Lund 1995; Lund 2002; Neves et al. 2009). Lund (2002) specifically notes how rural beneficiaries use grant income to secure credit, hire equipment and buy inputs. The cases of Nosomsi and Kwanele show how grant income provides seed and operating capital for retail and small-scale agrarian production. Barrientos (2008) notes that transfers have the greatest effects amongst rural households with deficits in complementary 'productive' assets such as inputs or labour, which often channel social grants to overcome these (Neves et al. 2009).

Finally, the income from social transfers potentially serves as a stimulus to local growth by increasing purchasing power and generating multiplier effects. International evidence finds increases in consumption and productive assets among non-beneficiaries in receiving areas, relative to control groups (Angelucci and De Giorgi 2009), but the precise magnitude of the multiplier effects is difficult to judge and is typically calculated for grant beneficiaries alone. Within South Africa, social transfers are received by large numbers of recipients located in particular kinds of spatial poverty traps, the ethnic enclaves of the former homelands and urban townships.These are resource-poor areas that continue to bear the mark of apartheid-era spatial planning, which repressed the formation of conventional settlement patterns or functioning local markets. Social transfers therefore provide a demand side stimulus for local trade. Some have suggested that they stimulate the development of local markets (Neves et al. 2009; Barrientos and Sabates-Wheeler 2010). While others find more modest and differentiated evidence for local multiplier effects (Aliber et al. 2007), social grant income indubitably provides uncommon cash liquidity in rural areas.

\section{Social reciprocity}

A fourth and final component of dealing with rural poverty are the elaborate, culturally embedded and spatially distributed practices of mutual exchange and social reciprocity. These practices underpin both inter- and intra-household transfers, and animate urban-rural linkages and household livelihood activities. They receive various explanatory inflections in the theoretical literature, including as 'social capital', or 'ubuntu', in an Africanist register (Du Toit and Neves 2009a), or even 'informal social protection' (Bracking and Sachikonye 2006).

Although the poor hardly have a monopoly on practices of mutual exchange and social reciprocity, these are all the more important for them given the precariousness of their livelihood activities, their heightened vulnerability to downward plunges into immizeration, and the relative paucity of their access to formal risk-sharing or mitigation arrangements (such as insurance).

These practices of mutuality are simultaneously specific and diverse: they inhere in specific relationships but take on a wide range of forms. They cannot be conflated with transactional exchange, but are instead predicated on obligation and claimed through the 
exercise of entitlement, cultural norms and moral claims (Du Toit and Neves 2009b). Material and monetary exchanges of gifts, disbursements and remittances are one medium of exchange in relationships of social reciprocity; favours, gifts and other forms of value such as unremunerated care work are another.

These circuits of mutual assistance are apparent in several of the vignettes; for example, in the relationship between Nosomsi and her son Fikile. Fikile scaled back his remittance to his mother when she began to receive a state pension, but once he was more lucratively employed, the dance of obligation and entitlement between them increased in tempo. Fikile resumed his remittance, which endured throughout the research period.

The interplay of entitlement and obligation is also evident in Kwanele's cash remittances to his urban-based sons. These were made with the implicit understanding that the flow of resources and support would be reversed once the sons secured employment. For many rural households, the common imperative of educating children is part of a larger survival strategy to access the beachheads of urban economic opportunity, with the expectation that employed adult children will prospectively support the household. These expectations can also potentially be disavowed or rejected.10

These webs of social reciprocity are not limited to kinship relations. Nosomsi allowing other villagers and the petty elite teachers of the local school to store perishable items in her gas-powered refrigerator was not simply an act of decontextualized magnanimity; it was an accommodation that placed her favourably in local circuits of exchange and support. Similarly, Kwanele's dignified patriarchal deportment, his reputation as a successful and hard-working urban returnee, and the considerable material investment in his ecclesiastical project, suggest his local respectability and his place in village networks of mutuality. These networks of social reciprocity are invariably nested within larger relationships of kinship, clanship, village, ethnic affiliations and neighbourliness (Du Toit and Neves 2009a).

Although practices of mutuality and social exchange are crucial to the survival of the many impoverished South Africans and serve to ameliorate poverty, they are not without their disadvantages and costs. They exact resources, particularly in a context in which redistributive pressures are considerable and pervasive; for instance, Kwanele's frustrated attempts to sell spinach amidst requests that he provide it without charge. Practices and systems of social reciprocity also potentially transmit shocks throughout a social network. The case study of Chuma shows her, on balance, to be a loser in the kinship compact of obligation and entitlement. The ambivalent relational politics of altruism is also evident in Kwanele's dutiful resignation in the face of the need to support his dependent adult brothers.

In addition, the workings of social reciprocity are uneven in their benefits and distribution. Exchanges are crucially mediated by gender, age, wealth, status and power (Spiegel et al. 1996), which can create net beneficiaries and make others more marginal and

\footnotetext{
${ }^{10}$ For instance, disapprobation is reserved for 'itshipa', urban absconders or non-remitters who disavow the obligations of social reciprocity and exchange within migrant networks.
} 
vulnerable. Typically, those without material resources, or the ability to offer labour power, struggle to participate in these exchanges or do so on disadvantageous terms (Du Toit and Neves 2009a). Furthermore, a familiar fracture is gender, as the burden of social reproduction falls disproportionately on women (as in the case of Chuma). Intrahousehold resources are not ordered according to the logic of an altruistic maximization of household welfare, but as the outcome of intra-household contests and power relations (Sagner and Mtati 1999; Posel 2001). Finally, notions of legitimate entitlement and even household membership are not self-evident or determined by unproblematic 'norms of consanguinity, cultural codes of domesticity or normalised narrative of life cycle"' (Du Toit and Neves 2009a), but are the result of culturally inscribed negotiation and contestation.

\section{Vulnerability and social differentiation}

This final section briefly considers how the practices of livelihood-making discussed reflect and shape social differentiation. South Africa's countryside is not only marked by widespread poverty and vulnerability, but also by high levels of social differentiation.

Rural households are shaped by their access to the various domains of livelihoodenabling factors described here: land-based endowments and linkages to urban resources, various informal economic activities, receipt of state cash transfers, and practices of social mutuality and reciprocity. As the extent and quality of access to these four domains vary widely between households, so to do the patterns of vulnerability and social differentiation that subsequently emerge. Among the vignettes discussed, differential access relative to these four domains is a key factor in shaping the relative vulnerability of each case, and the differences between them.

Social differentiation is both a constitutive condition and a consequence that can recursively generate the conditions of its own perpetuation. Therefore, differential patterns relative to the four key domains discussed above do not simply pattern social differentiation between economically marginalized rural households; they influence differentiation between households that are economically marginalized and those that are not. They invariably refract larger and enduring process of racialized dispossession, accumulation and vulnerability. Hence while processes of rural social differentiation unfold synchronically in the present, they have historical trajectories for rural areas, households and individuals.

An understanding of social differentiation is facilitated by attention to the interconnections between the domains that contribute to it. Examining poverty and vulnerability across urban and rural contexts, Du Toit and Neves (2006) developed a schematic four-part typology of varieties of impoverished households' 'connectedness' between urban and rural (Figure 1).

Rural households with an urban pole (top left quadrant 1) are analogues of the household diagonally across the typology: urban households with a rural pole (bottom right quadrant 4). 
Figure 1 A typology of varieties of household connectedness

\begin{tabular}{|l|l|}
\hline $\begin{array}{l}\text { 1. Rural households } \\
\text { with an urban pole }\end{array}$ & $\begin{array}{l}\text { 2. Urban households } \\
\text { without a rural pole }\end{array}$ \\
\hline $\begin{array}{l}\text { 3. Rural households } \\
\text { without an urban pole }\end{array}$ & $\begin{array}{l}\text { 4. Urban households } \\
\text { with a rural pole }\end{array}$ \\
\hline
\end{tabular}

Source: Adapted from du Toit and Neves (2006).

United by widespread reciprocity and resource-sharing in spatially extended households, these are often twin poles of the same households. In relation to the small sample of households discussed, this variety of household is among the most diversified and (comparatively) least vulnerable of all, including those of Kwanele, and especially Ramena. Households characterized by these linkages are amongst those most likely to accrue the levels of assets and labour required for farming. This accords with other evidence: while rural households that successfully engage in small-scale agriculture are poor, statistically they are not the very poorest (Palmer and Sender 2006).

Households with urban links are more likely to have the requisite resources and complementary assets such as cattle, historically correlated with crop production (cf. Heron 1991). Cattle ownership is an important signifier of difference in the former homelands, where 1.4 million African households have no livestock larger than fowls, and almost a million households report no access to arable land at all (Aliber 2003). Ownership of cattle in the former homelands is also noteworthy because of evidence that it has become more unequal over time (Cousins 1996). Consistent with larger societal trajectories of inequality and differentiation, cattle ownership has become largely concentrated in the hands of local petty elites or households with solid formal-sector employment. In this way, urban linkages and resources, either in the present or the recent past (in the case of accumulated retirement savings or retrenchment benefits), are significant, while their absence is typically a marker of vulnerability and social differentiation. While receipt of a higher-value social grant (SOAG or Disability Grant) might elevate households above the most vulnerable and impoverished, it serves, at best, as a complementary adjunct to urban linkages (as in the case of Nosomsi).

The top right quadrant of the typology (number 2), is occupied by urban households without a strong rural pole - a diverse and varied group, some of whom had successfully made the urban transition and were investing (or had invested) in both material and social terms, in continued urban residency. While they may retain some affective links to specific rural locales - for instance, visiting during holiday time (such as Christmas) or for traditional ceremonies - they typically reduce their rural links and commitments. In the course of research, respondents' answers to questions concerning their anticipated place of retirement and eventual place of burial often served as a litmus test for their degree of urban orientation. These urbanites and aspirant urbanites also included a potentially far more vulnerable subset of respondents who had lost their rural linkages or claims to rural entitlements. Although this subset of households was beyond the purview of the current analysis, Ferguson's (1999) account of urban decline in the Zambian 
Copperbelt documents the dislocation and adversity encountered by urbanites in their retreat to rural areas to which they had retained few connections or entitlements.

The final quadrant and group in this typology (quadrant 3, bottom left) are rural households without an urban pole. These were comparatively few in number, and represented some of the most vulnerable and marginalized of all households studied, exemplified by the case of Chuma. These households were generally poorly located in circuits of mutual support and exchange, and noteworthy for the extent to which their members were socially atomized and extremely vulnerable, even by the impoverished standards of the former homelands (Du Toit and Neves 2009a). This vulnerability may, in methodological terms, make the task of capturing them analytically more challenging. This variety of households often does not feature prominently in networks of social reciprocity and, as suggested by the substantial changes in Chuma's household composition, teeters close to the prospect of household dissolution as well as destitution. Connections to urban opportunities and markets are dynamic, partially reflecting the developmental cycle of household formation, reproduction and dissolution, but also broader translocal changes. Chronic African unemployment, intensified by practices of labour externalization and growth in precarious employment, has shaped the prospects for formal African employment and its material provisioning for retirement. It has also coincided with the changing regimes of retirement benefits since the $1980 \mathrm{os}$, in the shift from defined benefit private pensions to defined contribution retirement savings (including provident funds). 'Externalization' and worker resistance to industrial paternalism means that (typically male) retired employees are relatively unlikely to access a modest lifelong pension, but might receive accrued provident fund savings, a sum sometimes equivalent to several multiples of the annual value of the SOAG (Du Toit and Neves 2006). Many, such as Kwanele, drew these down relatively rapidly, exhausting the money after a short number of years. Hence changing regimes of private retirement funding displaced the responsibility and risks for managing the funds on to poorly educated workers with relatively low levels of financial literacy. These developments are a new reality in the material base of many rural livelihoods. They also represent a legacy that is likely to dissipate with the loss of formal workplace benefits by larger proportions of low-wage workers in South Africa. Changing formal-sector and urban gains therefore come to shape rural locales and entitlements. In this way, vulnerability and dispossession are not only ongoing processes; they take new forms with new stresses (Hart 1996).

\section{Conclusion}

This paper examines the interconnections between land, employment and rural livelihoods, in order to understand the survival of the rural poor in contemporary South Africa. It suggests that combinations of land-based entitlements, informal farm and nonfarm economic activities, state social assistance and practices of social reciprocity are key to the livelihoods of the rural poor. These constitutive elements are not conceptualized as highly compartmentalized, but their interconnections are explored, in order to understand better and be able to theorize lives and livelihoods in the South African countryside - not only the complex and contingent quality of rural livelihoods, and how they shaped by urban connections, but also how they reflect and feed into patterns of rural social differentiation.

REFERENCES 
Aliber, M., 2003.'Chronic Poverty in South Africa: Incidence, Causes and Policies'. World Development, 31 (3): 473-90. Aliber, M. and T. Hart, 2009. 'Should Subsistence Agriculture be Supported as a Strategy to Address Rural Food Insecurity?' Agrekon, 48 (4): 434-58.

Aliber, M., M. Kirsten, R. Maharajh, J. Nhlapo-Hlope and O. Nkoane, 2006. 'Overcoming Underdevelopment in South Africa's Second Economy'. Development Southern Africa, 23 (1): 45-61.

Aliber, M., T. Maluleke, T. Manenzhe, G. Paradza and B. Cousins, forthcoming. Livelihoods after Land Reform: Trajectories of Change in Northern Limpopo Province, South Africa. Cape Town: HSRC Press.

Aliber, M., Y.D. Davids, S. Sedumedi, S. Mazibuko, B. Mncwango and M. Diko, 2007. The Economic Impact of Welfare Grants on Selected KwaZulu-Natal Communities, Study Commissioned by the Department of Economic Development, KwaZulu-Natal. Pretoria: Human Sciences Research Council.

Andrew, M. and R.C. Fox, 2004. "Undercultivation" and Intensification in the Transkei: A Case Study of Historical Changes in the Use of Arable Land in Nompa, Shixini'. Development Southern Africa, 21 (4): 687-706.

Angelucci, M. and G. De Giorgi, 2009.'Indirect Effects of an Aid Program: How Do Cash Transfers Affect Ineligibles' Consumption?' The American Economic Review, 99 (1): 486-508.

Ardington, E. and F. Lund, 1995. 'Pensions and Development: Social Security as Complementary to Programmes of Reconstruction and Development'. Development Southern Africa, 12 (4): 557-77.

Bank, L., 1997. 'Of Livestock and Deadstock: Entrepreneurship and Tradition on the South African Highveld'. In

Farewell to Farms: De-agrarianisation and Employment in Africa, eds D. Bryceson, and V. Jamal, Aldershot: Ashgate.

Bank, L., 2002.'Beyond Red and School: Gender,Tradition and Identity in the Rural Eastern Cape'. Journal of Southern African Studies, 28 (3): 631-49.

Bank, L. and G. Minkley, 2005. 'Going Nowhere Slowly? Land, Livelihoods and Rural Development in the Eastern Cape'. Social Dynamics, 31(1):1-38.

Barrientos, A., 2008. 'Social Transfers and Growth: A Review'. Working Paper No. 112. Manchester: Chronic Poverty Research Centre, University of Manchester.

Barrientos, A. and R. Sabates-Wheeler, 2010. 'Do Transfers Generate Local Economy Effects?' BWPI Working Paper No. 106. Available at SSRN: http://ssrn.com/abstract=1545897 (accessed 11 November 2011).

Bertrand, M., D. Mullainathan and D. Miller, 2003. 'Public Policy and Extended Families: Evidence from Pensions in South Africa'. World Bank Economic Review, 17 (1): 27-50.

Black, A., 2010. 'Tilting the Playing Field: Labour Absorbing Growth and the Role of Industrial Policy'. CSSR Working Paper No. 279. Cape Town: Centre for Social Science Research, University of Cape Town.

Black, A. and S.B. Kahn, 2002. 'Growing without Gold? South Africa's Non-traditional Exports since 1980'. In Non-Traditional Export Promotion in Africa: Experience and Issues, ed. G. Helleiner, 217-52. Basingstoke: Palgrave.

Budlender, D. and I. Woolard, 2006. The Impact of South African Child Support and Old Age Grants in Children's Schooling and Work. International Programme on the Elimination of Child Labour. Geneva: International Labour Office. 
Bundy, C., 1979. The Rise and Fall of the South African Peasantry. London: James Currey.

Bracking, S. and L. Sachikonye, 2006. 'Remittances, Poverty Reduction and the Informalisation of Household Wellbeing in Zimbabwe'. GPRG-WPS-045. Global Poverty Research Group, http://www.gprg.org/pubs/ workingpapers/default.htm (accessed 20 June 2007).

Bryceson, D.F., 1996. 'Deagrarianisation and Rural Unemployment in Sub-Saharan Africa: A Sectoral Perspective'. World Development, 24 (1): 97-111.

Bryceson, D.F. and V.Jamal, eds, 1997. Farewell to Farms: De-agrarianisation and Employment in Africa. Aldershot: Ashgate. Case, A. and A. Deaton, 1998. 'Large Cash Transfers to the Elderly in South Africa'. The Economic Journal, 108 (450): 1330-61.

Case, A., V. Hosegood and F. Lund, 2005. 'The Reach and Impact of Child Support Grants: Evidence from KwaZulu-Natal'. Development Southern Africa, 22 (4): 467-82.

Cichello, P., G.S. Fields and M. Leibbrandt, 2005. 'Earnings and Employment Dynamics for Africans in PostApartheid South Africa: A Panel Study of KwaZulu-Natal'. Journal of African Economies, 14 (2): $143-90$.

Comaroff, J. and J. Comaroff, 1991. Of Revelation and Revolution: Christianity, Colonialism and Consciousness in South Africa. Chicago: University of Chicago Press.

Cousins, B., 1996.'Livestock Production and Common Property Struggles in South Africa's Agrarian Reform'. Journal of Peasant Studies, 23 (2-3):166-208.

Davis, M., 2006. Planet of Slums. London:Verso.

Delius, P., 1996. A Lion amongst the Cattle: Reconstruction and Resistance in the Northern Transvaal.Johannesburg: Ravan Press.

Devereux, S., 2001. 'Livelihood Insecurity and Social Protection: A Re-emerging Issue in Rural Development'. Development Policy Review, 19 (4):507-19.

Devey, R., C. Skinner and I. Valodia, 2005. 'The State of the Informal Economy'. In The State of the Nation 2005-6, eds S. Buhlungu, J. Daniel, J. Lutchman and R. Southhall, 223-47. Cape Town: HSRC Press.

Devey, R., C. Skinner and I. Valodia, 2006. 'Second Best? Trends and Linkages in the Informal Economy in South Africa’. DPRU Working Paper 06/102. Development Policy Research Unit. Cape Town: University of Cape Town.

Du Toit, A. and D. Neves, 2006. Vulnerability and Social Protection at the Margins of the Formal Economy, Case Studies from Khayelitsha and the Eastern Cape. Report for the National Treasury. Bellville: PLAAS/Pretoria: USAID, http://www.plaas.org.za/publications/downloads/vulnerability.pdf/ (accessed 30 January 2012).

Du Toit, A. and D. Neves, 2007a. Understanding Self-Employment at the Margins of the South African Economy. Findings from a Pilot Study on Qualitative Approaches to Self-Employment. Report for the National Income Dynamics Study Steering Committee. Cape Town: Institute for Poverty Land and Agrarian Studies

Du Toit, A. and D. Neves, 2007b. 'In Search of South Africa's Second Economy'. Africanus, 37 (2):14574.

Du Toit, A. and D. Neves, 2009a.'Informal Social Protection in Post-Apartheid Migrant Networks:Vulnerability, Social Networks and Reciprocal Exchange in the Eastern and Western Cape, South Africa'. Working Paper 74. Brooks World Poverty Institute. Manchester: University of Manchester, http://www.bwpi.manchester.ac.uk/resources/ Working-Papers/index.html (accessed 12 March 2010).

Du Toit, A. and D. Neves, 2009b. 'Trading on a Grant: Integrating Formal and Informal Social Protection in Post-Apartheid Migrant Networks'. Working Paper 75. Brooks World Poverty 
Institute. Manchester:

Duflo, E., 2003. 'Grandmothers and Granddaughters: Old-Age Pensions and Intra-Household Allocation in South Africa'. The World Bank Economic Review, 17(1):1-25.

Ferguson, J., 1992. 'The Cultural Topography of Wealth: Commodity Paths and the Structure of Property in Rural Lesotho', American Anthropologist, 94 (1): 55-73.

Ferguson, J., 1999. Expectations of Modernity: Myths and Meanings of Urban Life on the Zambian Copperbelt. Berkeley, CA: University of California Press.

Guyer, J., 2004. Marginal Gains: Monetary Transactions in Atlantic Africa. Chicago: University of Chicago Press. Handelman, D., 2005. 'Microhistorical Anthropology: Towards a Prospective Perspective'. In Critical Junctions: Anthropology and History beyond the Cultural Turn, eds D. Kalb and H. Tak, 29-52. New York: Berghahn Books.

Hart, G., 1996. 'The Agrarian Question and Industrial Dispersal in South Africa: Agro-Industrial Linkages through Asian Lenses'. Journal of Peasant Studies, 23(2-3), 245-77.

Hart, G., 2002. Disabling Globalization Place of Power in Post-Apartheid South Africa. Berkeley, CA: University of California Press.

Hart, K., 1973. 'Informal Income Opportunities and Urban Employment in Ghana'. Journal of Modern African Studies, 11: 61-89.

Hendricks, F.T., 1990. 'The Pillars of Apartheid: Land Tenure, Rural Planning and the Chieftaincy'. PhD dissertation, Department of Sociology, University of Uppsala.

Heron, G.S., 1991. 'The Household, Economic Differentiation and Agricultural Production in Shixini, Transkei'. Development Southern Africa, 8 (1): 47-60.

Hochschild, A.R., 2000. 'Global Care Chains and Emotional Surplus Value'. In On the Edge: Living with Global Capitalism, eds W. Hutton and A. Giddens, 130-46. London: Jonathan Cape.

Hoogeveen, J. and B. Özler, 2006. 'Poverty and Inequality in Post-Apartheid South Africa 1995-2000'. In Poverty and Policy in Post-Apartheid South Africa, eds H. Bhorat and R. Kanbur, 59-94. Pretoria. HSRC Press.

Hunter, M., 2005.'Cultural Politics and Masculinities: Multiple-Partners in Historical Perspective in KwaZulu-Natal'.

Culture, Health \& Sexuality: An International Journal for Research, Intervention and Care, 7 (4): $389-403$.

Hunter, N., 2006. 'Crises in Social Reproduction in a Developmental State: Home-Based Care in KwaZuluNatal'. Paper presented at Colloquium on the Economy, Society and Nature. Durban, University of Natal, Centre for Civil Society.

James, D., 2000. 'After Years in the Wilderness: The Discourse of Land Claims in the New South Africa'. Journal of Peasant Studies, 27(3): 142-61.

James, D., 2001. 'Land for the Landless: Conflicting Images of Rural and Urban in South Africa's Land Reform Programme'.Journal of Contemporary African Studies, 19 (1): 93-109.

Keswell, M., 2004. 'Non-Linear Earning Dynamics in Post-Apartheid South Africa'. South African Journal of Economics, 72 (5): 913-39.

Kingdon, G.G. and J. Knight, 2000.'Unemployment in South Africa: The Nature of the Beast'. World Development, 32 (3):391-408.

Leibbrandt, M.I. Woolard, A. Finn and J. Argent, 2010. 'Trends in South African Income Distribution and Poverty since the Fall of Apartheid'. OECD Social, Employment and Migration Working Papers, No. 101. Paris: OECD Publishing, http://dx.doi.org/10.1787/5kmmsot7p1ms-en (accessed 15 February 2012). 
Lund, F., 2002. “"Crowding In” Care, Security and Micro-Enterprise Formation: Revisiting the Role of the State in Poverty Reduction and in Development'. Journal of International Development, 14 (6): 681-94.

Lund, F., 2006. 'Gender and Social Security in South Africa'. In The Development Decade? Economic and Social Change in South Africa 1994-2004, ed. Y. Padayachee. 160-81. Pretoria: HSRC Press.

Lund, F. and F. Skinner, 2003. 'Integrating the Informal Economy in Urban Planning and Governance: A Case Study of the Process of Policy Development in Durban, South Africa'. International Development Planning Review, 26 (4): 431-56.

McAllister, P., 2001. Building the Homestead: Agriculture, Labour and Beer in South Africa's Transkei. Aldershot: Ashgate. Mabin, A., 1990. 'Limits of Urban Transition Models in Understanding South African Urbanisation'. Development Southern Africa, 11 (3): 311-22.

Mamdani, M., 1996. Citizen and Subject. Princeton, NJ: Princeton University Press.

Manona, C., 1998. 'Land Tenure and Use: Perspectives from a Village in the Eastern Cape, South Africa'. African Sociological Review, 2 (2):77-89.

May, J., I. Woolard and S. Klasen, 2000. 'The Nature and Measurement of Poverty and Inequality'. In Poverty and Inequality in South Africa: Meeting the Challenge, ed. J. May, 73-96. Cape Town: David Philip.

Meagher, K., 2010. Identity Economics: Social Networks and the Informal Economy in Nigeria. London: James Currey. Morrell, R. and S. Swart, 2005. 'Men in the Third World: Postcolonial Perspectives on Masculinity'. In Handbook of Studies on Men and Masculinities, eds R.W. Connell, J. Hearn and M. Kimmel, 90-113. Thousand Oaks, CA: SAGE Publications.

Ngwane, Z., 2003. " "Christmas Time" and the Struggles for the Household in the Countryside: Rethinking the Cultural Geography of Migrant Labour in South Africa'. Journal of Southern African Studies, 29 (3): 681-99.

Neves, D. and A. du Toit, 2012. 'Money and Sociality in South Africa's Informal Economy'. Africa, 82 (1): 131-49.

Neves, D., M. Aliber, J. Mogaladi and A. du Toit, 2011. Understanding Informal SelfEmployment: A Qualitative- Quantitative Integrated Study. Research Report to Programme to Support Pro-Poor Policy Development (PSPPD), Office of the Presidency. Cape Town:Institutefor Poverty Land and Agrarian Studies (PLAAS), University of the Western Cape.

Neves, D., M. Samson, I. van Niekerk, S. Hlatshwayo and A. du Toit, 2009. The Use and Effectiveness of Social Grants in South Africa. Research Report to FinMark Trust. Johannesburg: FinMark Trust.

Noble, M. and G. Wright, 2012. 'Using Indicators of Multiple Deprivation to Demonstrate the Spatial Legacy of Apartheid in South Africa'. Social Indicators Research, doi:10.1007/s11205-0120047-3:1-15, http://www. springerlink.com/content/n841u7072422j14r/fulltext.pdf (accessed 4 July 2012).

Ntsebeza, L., 2006. Democracy Compromised: Chiefs and the Politics of Land in South Africa. Pretoria: HSRC Press. Palmer, K. and J. Sender, 2006.'Prospects for On-Farm Self-Employment and Poverty Reduction: An Analysis of the South African Income and Expenditure Survey 2000'. Journal of Contemporary African Studies, 24 (3): 347-76.

Pauw, K. and L. Mncube, 2007. Expanding the Social Security Net in South Africa: Opportunities, Challenges and Constraints. International Poverty Centre. United Nations Development Programme. Brasilia: UNDP.

Petersen, L. and A. Charman, 2008. Making Markets Work for the Poor - Understanding the Informal Economy in Limpopo. Final Report. Research Support to the Limpopo Centre for LED. CapeTown:Sustainable Livelihood Consultants/Cardno Agrisystems. 
Philip, K., 2010. 'Inequality and Economic Marginalisation: How the Structure of the Economy Impacts on Opportunities on the Margins'. Law, Democracy and Development, 14:1-28.

Pillay, U., 2008. 'Urban Policy in Post-Apartheid South Africa: Context, Evolution and Future Directions'. Urban Forum, 19 (2): 109-132.

Posel, D., 2001. 'Intra-family Transfers and Income-Pooling: A Study of Remittances in KwaZulu-Natal'. South Africa Journal of Economics, 69 (3):501-28.

Posel, D. and R. Devey, 2006. 'The Demographics of Fatherhood in South Africa: An Analysis of Survey Data, 1993-2002'. In Baba: Men and Fatherhood in South Africa, eds L. Richter and R. Morrell, 38-52. Pretoria: HSRC Press.

Posel, D., J. Fairburn and F. Lund, 2004.'Labour Migration and Households: A Reconsideration of the Effects of Social Pension on Labour Supply in South Africa'. Ninth Annual Conference on Econometric Modelling for Africa (30 June to 2 July 2004). CapeTown:University of Cape Town.

Potts, D., 2000. 'Worker-Peasants and Farmer-Housewives in Africa: The Debate about "Committed" Farmers, Access to Land and Agricultural Production'. Journal of Southern African Studies, 26 (4): 807-32.

Richter, L. and R. Morrell, eds, 2006. Baba: Men and Fatherhood in South Africa. Pretoria: HSRC Press.

Rogerson, C.M., 2007. "Second Economy” versus Informal Economy: A South African Affair'. Geoforum, 38: 1053-7. Roitman, J., 2005. Fiscal Disobedience: An Anthropology of Economic Regulation in Central Africa. Princeton, NJ: Princeton University Press.

Ross, F., 2003. 'Dependents and Dependence: A Case Study of Housing and Heuristics in an Informal Settlement in the Western Cape'. Social Dynamics, 29 (2):132-52.

Sadoulet, E., A. de Janvry and B. Davis, 2001. 'Cash Transfer Programs with Income Multipliers: PROCAMPO in Mexico'. World Development, 29 (6):1043-56.

Sagner, A. and R. Mtati, 1999. 'Politics of Pension Sharing in Urban South Africa'. Ageing and Society, 19: 393-416.

Samson, M., U. Lee, A. Ndlebe, K. MacQuene, I. Van Niekerk, V. Gandhi, T. Harigaya and A. Abrahams, 2004. The Social and Economic Impact of South Africa's Social Security System. Final Report Executive Summary. Report commissioned by Economics and Finance Directorate, Department of Social Development, South Africa. Cape Town: Economic Policy Research Unit.

SASSA, 2012. Fact Sheet No. 4 of 2012 Summary of Social Grants Distribution in South Africa as at 30 April 2012. Fact Sheet. South African Social Security Agency. Pretoria: SASSA, http://www.sassa.gov.za/Portals/1/Documents/815477a6-9e37-4590-a785-7b934f045e52.pdf (accessed 14 June 2012).

Seekings, J., 2002. 'The Broader Importance of Welfare Reform in South Africa'. Social Dynamics, 28 (2): 1-38. Seekings, J., 2008.'Beyond "Fluidity": Kinship and Households as Social Projects'. CSSR Working Paper no. 237. Cape Town:Centre for Social Science Research, University of Cape Town.

Seekings, J. and S. Harper, 2010. 'Claims on and Obligations to Kin in Cape Town, South Africa'. CSSR Working Paper No. 272. Cape Town: Centre for Social Science Research, University of Cape Town.

Seekings, J. and N. Nattrass, 2005. Race, Class and Inequality in South Africa. New Haven, CT: Yale University Press.

Seekings, J., J. Graaff and P. Joubert, 1990. 'Survey of Residential and Migration Histories of Residents of the Shack

Areas of Khayelitsha'. Occasional Paper No. 15. Stellenbosch: Research Unit for Sociology of Development, University of Stellenbosch. 
Shackelton, C.M., S.E. Shackelton and B. Cousins, 2001. 'The Role of Land-Based Strategies in Rural Livelihoods: The Contribution of Arable Production, Animal Husbandry and Natural Resource Harvesting in Communal Areas of South Africa'. Development Southern Africa, 18 (5): 581-604.

Spiegel, A., V. Watson and P. Wilkinson, 1996. 'Domestic Diversity and Fluidity among Some African Households in Greater Cape Town'. Social Dynamics, 22 (1): 7-30.

Van Averbeke, W. and T.B. Khosa, 2007. 'The Contribution of Smallholder Agriculture to the Nutrition of Rural Households in a Semi-Arid Environment in South Africa'. Water $S A, 33$ : 413-18.

Van der Berg, S., 1997. 'South African Social Security under Apartheid and Beyond'. Development South Africa, 4 (14): 140-64.

Von Broembsen, M., 2008. 'SMMEs, the Informal Sector and the "Second Economy" '. PLAAS Working Paper 10.

Cape Town: Institute for Poverty, Land and Agrarian Studies (PLAAS), University of the Western Cape.

Wolpe, H., 1972.'Capitalism and Cheap Labour Power in South Africa: From Segregation to Apartheid'. Economy and Society, 1(4):425-56.

Woolard, I. and S. Klassen, 2004. 'Determinants of Income Mobility and Household Poverty Dynamics in South Africa'. Journal of Development Studies, 41 (5): 865-97. 